\title{
Evaluation of Phytochemical, Antioxidant, and Memory-Enhancing Activity of Garuga pinnata Roxb. Bark and Bryophyllum pinnatum (Lam) Oken. Leaves
}

\author{
Ravin Bhandari (iD, ${ }^{1}$ Sabina Gyawali, ${ }^{1}$ Nisha Aryal, ${ }^{1}$ Devika Gaire, ${ }^{1}$ Kalpana Paudyal, ${ }^{1}$ \\ Abaru Panta, ${ }^{1}$ Pooja Panth, ${ }^{1}$ Dirgha Raj Joshi $\mathbb{D}^{,},{ }^{1}$ Rabindra Kumar Rokaya ${ }^{\mathbb{D}},{ }^{2}$ \\ Pramod Aryal $\mathbb{D}^{\mathrm{D}},{ }^{1}$ and Jitendra Pandey ${ }^{1}{ }^{1}$ \\ ${ }^{1}$ Department of Pharmacy, Crimson College of Technology, Affiliated to Pokhara University, Devinagar-11, Butwal 32900, Nepal \\ ${ }^{2}$ Department of Pharmacology, Karnali Academy of Health Science, Jumla, Chandannath 21200, Nepal
}

Correspondence should be addressed to Ravin Bhandari; ravinbhandari2000@gmail.com

Received 7 November 2020; Accepted 13 April 2021; Published 27 April 2021

Academic Editor: James Aquavella

Copyright (c) 2021 Ravin Bhandari et al. This is an open access article distributed under the Creative Commons Attribution License, which permits unrestricted use, distribution, and reproduction in any medium, provided the original work is properly cited.

\begin{abstract}
Garuga pinnata Roxb. (Burseraceae) is a medium-sized tree widely available all over the tropical regions of Asia. Bryophyllum pinnatum (Lam) Oken. (Crassulaceae) is an indigenous and exotic plant grown in tropical regions. Both plants have been used for their anti-inflammatory, antioxidant, anticancer, wound healing, antidiabetic activities, etc. This investigation was designed to explore the result shown by methanolic extract of Garuga pinnata bark and Bryophyllum pinnatum leaves, on cognitive power and retention of the memory in experimental mice along with quantification of phenolic compounds and DPPH radicals neutralizing capacity. The memory-enhancing activity was determined by the elevated plus-maze method in Scopolamine-induced amnesic mice, using Piracetam as allopathic and Shankhpushpi as ayurvedic standard drugs. Two doses (200 and $400 \mathrm{mg} / \mathrm{kg}$ p.o.) of both extracts were administered to mice up to 8 consecutive days; transfer latency of individual group was recorded after 45 minutes and memory of the experienced things was examined after 1 day. DPPH assay method and the Folin-Ciocalteu method were employed to determine antioxidant potency and total phenol amount, respectively. $400 \mathrm{mg} / \mathrm{kg}$ of the methanolic B. pinnatum bark extract significantly improved memory and learning of mice with transfer latency (TL) of $32.75 \mathrm{~s}$, which is comparable to that of standard Piracetam (21.78 s) and Shankhpushpi $(27.83 \mathrm{~s})$. Greater phenolic content was quantified in B. pinnatum bark extract $(156.80 \pm 0.33 \mu \mathrm{g} \mathrm{GAE} / \mathrm{mg}$ dry extract) as well as the antioxidant potency $(69.77 \%$ of free radical inhibition at the $100 \mu \mathrm{g} / \mathrm{mL}$ concentration). Our study proclaimed the scientific evidence for the memory-boosting effect of both plants.
\end{abstract}

\section{Introduction}

Memory is a vital process by which experiences are recorded and can be used to adapt their responses to the environment. Alzheimer's disease (AD) is a major condition related to memory impairment and it can be characterized as a continuous neurodegenerative disorder that can lead to senile dementia, particularly in the cortex and hippocampus region. Besides distinct clinical manifestations, behavioral hallmarks involve progressive loss in memory, judgment capacity impairment, decision-making problem, physical atmosphere orientation, and language problem [1]. Studies of patients with $\mathrm{AD}$ revealed the decreasing levels of acetylcholine in the brain [2]. Although there are many treatment options available to treat $\mathrm{AD}$, due to the lack of complete efficacy and side effects, the interest in plant-based herbal medicine is increasing nowadays.

Shankhpushpi is a widely used herbal drug in the management of cognitive disorders, from the times of Acharya Charak (200 BC) to date [3]. Shankhpushpi has been categorized as a Medhya Rasayana, that is, an efficient brain tonic by Ayurvedic texts. According to the Ayurvedic 
Pharmacopeia of India, the whole parts of Convolvulus pluricaulis Choisy are approved for medicinal uses [4]. Based on their potentiality to treat memory-related dysfunctions and shape of the flower, the other three botanicals, namely, Clitoria ternatea Linn., Canscora decussata Schult., and Evolvulus alsinoides Linn. are also categorized as Shankhpushpi by Indian practitioners [5]. It is most commonly indicated for anxiety, depression, mental illness, seizure, sleeplessness, burning pain, hyperlipidemia, urinary complications, and edema. It has been reported that Shankhpushpi regulates epinephrine and hydrocortisone synthesis from the body $[4,6]$. Shankhpushpi increases the acetylcholine amount in the hippocampus region depending upon the dose administered that might contribute to its memory enhancement activity [7]. Neutralization of neurotoxic free radicals along with enhancement of the neurite outgrowth also plays a vital role in this effect $[8,9]$.

Bryophyllum pinnatum (Crassulaceae) is abundantly distributed in the tropical and subtropical regions around the world. Aerial parts or entire plant can be utilized to manage hypertension, syphilis, jaundice, candidiasis, dysmenorrhea, convulsions, and so forth. Many bioactive compounds, like bryotoxin A, B, C, caffeic acid, and protocatechuic acid, have been reported from this plant [10] that exhibit various activities like antioxidant, antiulcer, analgesic activity [11]; antiurolithiasis; and so forth [12].

Garuga pinnata (Burseraceae) is a deciduous plant found in India and east and south parts of Asia. It has been reported that $G$. pinnata extracts exhibited antiulcer, anticancer, antibacterial, antidiabetic, and antioxidant activity [13]. Ethnomedicinally, in Nepal, decoction from the leaf of B. pinnatum and bark of $G$. pinnata is used by the ethnic groups of the Tharu community to enhance memory. However, there is no scientific evidence on this ethnomedicinal claim. Thus, our study is mainly focused on investigating the memory-improving effect of these two plants along with their antioxidant activity.

\section{Materials and Methods}

2.1. Chemicals. The chemicals used are Piracetam and Scopolamine hydrobromide (Asian Pharmaceuticals, Nepal), Shankhpushpi (Bhagvati Herbal and Healthcare Private Limited, India), ascorbic acid (Merck), DPPH (Sigma-Aldrich), sodium bicarbonate (Fisher Scientific), hydrochloric acid, mercuric chloride, potassium chloride, ferric chloride, lead acetate, and Kagnesium ribbon (SD finechem limited).

2.2. Plants Collection and Extraction. G. pinnata and B. pinnatum were collected from Boadgoau, Kapilvastu, Nepal $\left(27.5518^{\circ} \mathrm{N}, 83.0469^{\circ} \mathrm{E}, 107 \mathrm{~m}\right.$ altitude from sea level) during September 2019 and were identified by National Herbarium and Plant Laboratories, Nepal. The herbarium voucher specimens of the plants have been deposited in the pharmacognosy laboratory of Crimson College of Technology (CCT-HRB-075-187 (G. pinnata) and CCT-HRB075-188 (B. pinnatum)). Bark and leaves of both plants were shade dried; comminuted to fine powder and extraction was carried out by the triple maceration process using methanol as the menstruum. The extracts were dried with the help of the rotary vacuum evaporator at $45^{\circ} \mathrm{C}$ and sticky dried extract was obtained which was further stored at $4^{\circ} \mathrm{C}$ until use.

2.3. Phytochemical Screening. Preliminary screening for the presence of secondary metabolites in the sample was performed by using previously described methods with slight modifications [14-16].

2.4. Total Phenol Content (TPC). For the determination of TPC, the Folin-Ciocalteu method was adopted [17]. TPC was calculated from the calibration curve of the Gallic acid and presented in the terms of $\mu \mathrm{g}$ gallic acid equivalent (GAE)/mg extracts.

2.5. Antioxidant Potency Measurement. The potency of the plant extracts to neutralize the DPPH free radicals was determined by the previously established method [18]. Ethanol and ascorbic acid were used as the blank sample and standard sample, respectively. The percentage of radical scavenged was calculated from the following equation:

percentage of radical neutralized $=[(A 0-A 1) / A 0] * 100 \%$.

Here, $A_{0}$ denoted the DPPH solution absorbance and $A_{1}$ denoted the test sample absorbance.

2.6. Animal's Ethical Approval and Acute Toxicity Studies. Male and female Swiss albino mice (25-30 g) were placed inside polypropylene cages with standard feed and water ad libitum. Animal handling, care, and experimental design were conducted according to the guidelines of the Institutional Review Committee, Nepal Health Research Council (Ref. no. 622/2019). Experimental animals were acclimatized for two weeks before experimental procedures [19-21]. Guidelines given by the Organization of Economic Cooperation and Development were employed to study acute toxicity in the experimental animal [22].

\subsection{Memory-Enhancing Activity}

2.7.1. Elevated Plus-Maze Method. Elevated plus-maze and Scopolamine-induced amnesia were used for the exteroceptive and interoceptive behavior design, respectively, to monitor the cognitive power and retention of the memory, according to a previously established method with slight modification [23].

The elevated plus-maze having 2 open arms $(16 \times 5$ centimeters), 2 closed arms $(16 \times 5 \times 12$ centimeters $)$ raised vertically with the 25 -centimeter height was applied. Individual experimental animals were kept at the edge of the open arm facing far from the middle rostrum; then, total duration for moving from the edge of the open arm to both 


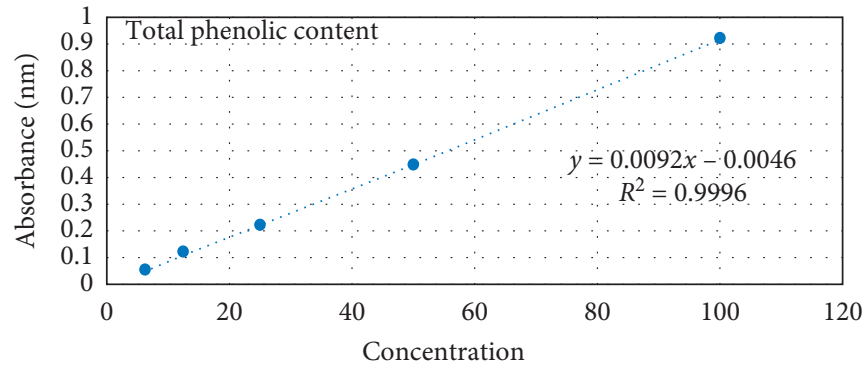

FIGURE 1: Calibration curve of gallic acid standard for total phenolic content. Concentrations of the gallic acids were prepared in $\mu \mathrm{g} / \mathrm{mL}$.

closed arms using all legs (Transfer latency, TL) was noted. Those animals that failed to reach inside any closed arm in a period of $90 \mathrm{sec}$ were kindly propelled toward closed arms and TL was considered to be $90 \mathrm{~s}$. The mice were permitted to search the maze for the next $10 \mathrm{~s}$ and afterward come back to the cage. Memory of this experienced work was investigated 1 day after the initial examination day.

Transfer latency after 1 day was interpreted in the terms of Inflection Ratio (IR), by applying the following equation:

$$
\mathrm{IR}=(L 1-\mathrm{L} 0) / \mathrm{L} 0 \text {, }
$$

where $L_{0}$ is the transfer latency after 1 day and $L_{1}$ is the first transfer latency expressed as seconds.

2.7.2. Experimental Design. A total of 48 mice were classified into 8 groups $(n=6)$. All groups except for vehicle control (Group I) were treated with Scopolamine hydrobromide $(0.4 \mathrm{mg} / \mathrm{kg})$ intraperitoneally, on the eighth day of extract/ standard drug treatment to induce amnesia. Transfer latency was recorded after 45 minutes and the memory of experienced things was evaluated after 1 day in every classification:

(1) Group I : vehicle control

(2) Group II : Scopolamine control

(3) Group III:B. pinnatum leaves test sample $(200 \mathrm{mg} / \mathrm{kg})$

(4) Group IV:B. pinnatum leaves test sample (400 $\mathrm{mg} / \mathrm{kg})$

(5) Group V:G. pinnata bark test sample $(200 \mathrm{mg} / \mathrm{kg})$

(6) Group VI: G. pinnata bark test sample (400 mg/kg)

(7) Group VII : Shankhpushpi (5-fold dilution)

(8) Group VIII : Piracetam (100 mg/kg)

2.8. Statistical Analysis. All the data were presented in terms of average \pm SD. The mean differences between the different classes were calculated with the help of one-way ANOVA (MS-Excel 2019) and considered significant if $p<0.05$.

\section{Results}

3.1. Extractive Yield, Phytochemical Screening, and Total Phenolic Content. Extractive yield for the methanolic extract of G. pinnata bark and B. pinnatum leaves was 12.04 and $10.46 \%$, respectively. Qualitative phytochemical examination
TABle 1: Antioxidant activity of leaves of G. pinnata and barks of B. pinnatum. MGPB has significant antioxidant activity compared to MBPL in a dose-dependent manner.

\begin{tabular}{lccc}
\hline \multirow{2}{*}{ Conc. $(\mu \mathrm{g} / \mathrm{mL})$} & \multirow{2}{*}{ MBPL } & \multicolumn{2}{c}{ Percentage inhibition } \\
& & MGPB & AA \\
\hline 0.1 & $17.69 \pm 0.58$ & $24.07 \pm 0.123^{*}$ & $34.76 \pm 4.5^{* *}$ \\
1 & $22.35 \pm 0.11$ & $28.74 \pm 0.92^{*}$ & $42.48 \pm 3.51^{* *}$ \\
10 & $23.83 \pm 0.30$ & $40.78 \pm 0.67^{*}$ & $88.36 \pm 0.85^{* *}$ \\
100 & $47.42 \pm 0.69$ & $69.77 \pm 0.43^{*}$ & $95.25 \pm 1.44^{* *}$ \\
\hline
\end{tabular}

MBPL : methanolic extract of $B$. pinnatum leaf, MGPB : methanolic extract of G. pinnata bark, and AA : ascorbic acid. ${ }^{*} p<0.05$ and ${ }^{* *} p<0.01$ when correlated to MBPL (note: all the tests were done in triplicate).

revealed the occurrence of phenolic compounds, flavonoids, tannins, saponin, and alkaloids. The entire phenolic amount was quantified by utilizing the calibration curve of the standard gallic acid (Figure 1) and interpreted as gallic acid equivalent (GAE). The total phenolic content of $B$. pinnatum leaves and $G$. pinnata bark was found to be $27.782 \pm 0.25$ and $156.80 \pm 0.33 \mu \mathrm{g} \mathrm{GAE} / \mathrm{mg}$ dry extract, respectively.

3.2. Antioxidant Activity. According to Table 1, the DPPH radicals neutralizing activity shown by the methanolic extract of $G$. pinnata bark (MGPB) $\left(\mathrm{EC}_{50} 50.14 \mu \mathrm{g} / \mathrm{mL}\right)$ and methanolic extract of $B$. pinnatum leaf $(\mathrm{MPBL})$ extract $\left(\mathrm{EC}_{50}\right.$ $109.41 \mu \mathrm{g} / \mathrm{mL})$ revealed that they have a moderate antioxidant capacity in comparison to ascorbic acid standard $\left(\mathrm{EC}_{50}\right.$ $5.47 \mu \mathrm{g} / \mathrm{mL}$ ). Furthermore, the activity depends upon the dose used. The free radical neutralizing capacity of MGBP is greater as compared to the MBPL.

3.3. Acute Toxicity Test. After the continuous monitoring of MBPL and MGPB oral ingestion at different doses $(0.2,0.4$, 0.8 , and $1 \mathrm{~g} / \mathrm{kg}$ ), it was concluded that plant extracts have no acute toxicity.

3.4. Memory-Boosting Effect. We verified the memory-enhancing activity of the two ethnomedicinally claimed plants for the first time. Oral ingestion of the MBPL $(200 \mathrm{mg} / \mathrm{kg})$ for 8 consecutive days did not produce any prominent result on TL, on the $8^{\text {th }}$ and $9^{\text {th }}$ day whereas, at the higher dose $(400 \mathrm{mg} / \mathrm{kg})$, it exhibited an incredible reduction in $\mathrm{TL}$ $(p<0.05, p<0.005)$, on the $8^{\text {th }}$ and $9^{\text {th }}$ day, suggesting noteworthy enhancement in cognitive and remembrance 
TABLE 2: Memory-enhancing activity of plant extract.

\begin{tabular}{lccc}
\hline Group & $(\mathrm{TL}) 8^{\text {th }}$ day $(\mathrm{s})$ & (TL) $9^{\text {th }}$ day $(\mathrm{s})$ & IR \\
\hline Vehicle control (saline) & $35.05 \pm 3.17$ & $30.96 \pm 2.64$ & $0.132 \pm 0.288$ \\
Scopolamine $(0.4 \mathrm{mg} / \mathrm{kg})$ & $60.74 \pm 2.27$ & $66.67 \pm 0.76$ & $0.88 \pm 0.028$ \\
MBPL $(200 \mathrm{mg} / \mathrm{kg})+$ Scopolamine & $55.36 \pm 1.37^{* *}$ & $50.3 \pm 0.99^{* *}$ & $0.1 \pm 0.073$ \\
MBPL (400 mg/kg) + Scopolamine & $50.5 \pm 1.34^{* *}$ & $43.67 \pm 1.69^{* *}$ & $0.156 \pm 0.10$ \\
MGPB (200 mg/kg) + Scopolamine & $53.12 \pm 1.3^{*}$ & $32.67 \pm 1.85^{* *}$ & $0.163 \pm 0.061$ \\
MGPB (400 mg/kg) + Scopolamine & $39.16 \pm 2.69^{* *}$ & $27.83 \pm 2.9^{* *}$ & $0.194 \pm 0.2147$ \\
Shankhpushpi + Scopolamine & $36.16 \pm 2.51^{* *}$ & $0.299 \pm 0.141$ \\
Piracetam (100 mg/kg) + Scopolamine & $26.12 \pm 2.6^{* *}$ & $21.78 \pm 1.19^{* *}$ & $0.19 \pm 0.611$ \\
\hline
\end{tabular}

MBPL and MGBP at both tested doses significantly reversed memory impairments induced by Scopolamine and are comparable to that of both controls. MGPD ( $400 \mathrm{mg} / \mathrm{kg})$ exhibited the best memory-enhancing activity among all test samples, with minimum transfer latency time. All the data are calculated as average \pm SD; $n=6$. Data are statistically effective at ${ }^{*} p<0.05$ and highly effective at ${ }^{* *} p<0.005$ in comparison to Scopolamine.

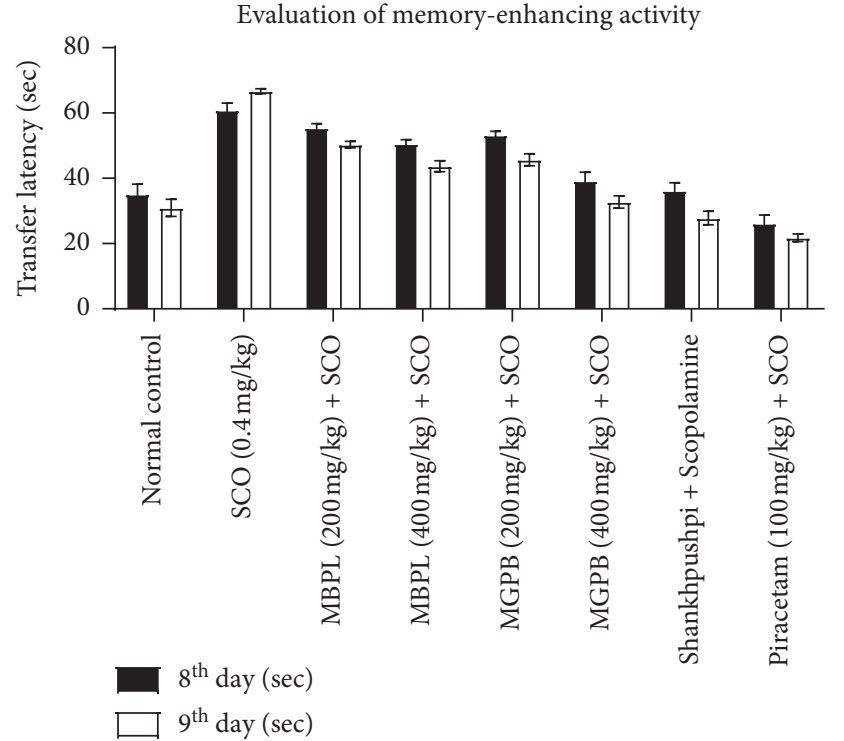

FIGURE 2: Bar diagram comparing the memory-enhancing activity of B. pinnatum leaves and $G$. pinnata barks with standard drug Piracetam and Shankhpushpi in the terms of transfer latency (SCO: Scopolamine, MBPL: Bryophyllum pinnatum leaves methanol extract, MGPB: Garuga pinnata bark methanolic extract).

power (Table 2 and Figure 2). MGDP extract at both doses exhibited remarkably higher memory-enhancing activity $(p<0.005)$ on the $8^{\text {th }}$ and $9^{\text {th }}$ day. Scopolamine hydrobromide $\left(0.4 \mathrm{mg} / \mathrm{kg}\right.$, i.p.) injected on the $8^{\text {th }}$ and $9^{\text {th }}$ days has high TL, indicating retardation in cognitive and remembrance power. Oral administration of the MBPL and MGPB at optimum doses (200 and $400 \mathrm{mg} / \mathrm{kg}$ up to 8 regular days) effectively improved Scopolamine produced memory loss. The results obtained from the plant extracts are comparable to the standard Piracetam and Shankhpushpi. However, Shankhpushpi showed better results than all the plant extracts.

\section{Discussion}

Preliminary screening of phytochemicals is an important step for detecting various bioactive secondary metabolites of plants, having a vital role towards beneficial medicinal and physiological activities such as antioxidant, antidiabetic, and anticancer activities [24]. Our study proclaimed the occurrence of bioactive compounds such as flavonoids, alkaloids, phenols, tannins, and saponins, which are similar to the results of another study for both plants $[25,26]$. Phenolic compounds display potent antioxidant effects by scavenging free radicals due to the presence of hydroxyl groups. Hence, quantitative phenolic content determination gives a clear idea about the antioxidant potency of plants and their biological activities. Greater phenolic content in the bark of $G$. pinnata $(156.80 \pm 0.33 \mu \mathrm{g}$ GAE/ $\mathrm{mg}$ ) than in $B$. pinnatum leaves $(27.782 \pm 0.25 \mu \mathrm{g}$ GAE/ $\mathrm{mg}$ ) reported in our study correlates the greater antioxidant activity observed and corresponds to the previous findings [27, 28]. Plant-derived free radical scavengers such as flavonoids and phenolic compounds are responsible for antioxidant activity [29].

DPPH free radical inhibition percentage data from $\mathrm{Ta}$ ble 2 demonstrates that methanolic extract of $G$. pinnata bark is more effective in inhibiting DPPH free radical compared to methanolic extract of B. pinnatum in all the tested concentrations. The higher amount of phenolic compounds might be the reason for better antioxidant potency of the G. pinnata bark extract. In a previous study, $40 \%$ of DPPH free radicle was found to be inhibited by $100 \mu \mathrm{g} / \mathrm{mL}$ of methanolic B. pinnatum extract [30]. In another study, the minimum effective concentration for ethanolic extract was found to be $144.09 \mu \mathrm{g} / \mathrm{mL}$ [31].

An elevated plus-maze model was adopted to determine the memory-enhancing efficacy of plant extracts in which Scopolamine was injected to induce amnesia in mice [23]. However, continued administration of both extracts facilitated better improvement of the memory acquisition and retention (proportional to the amount of dose administered) as compared to animals treated with Scopolamine, thus verifying nootropic effect [32]. In an elevated plus-maze model, reduced TL value suggested the upgrade of the cognitive power and vice versa. Recent studies have identified that this is an accepted model to study the learning and memory process in mice [33]. Immunological studies have shown that neuronal cell damage caused by inflammation can induce $\mathrm{AD}$ and prolonged use of anti-inflammatory agents can reduce the severity of this disease by inhibiting onset and the progression of $\mathrm{AD}[1,23]$. Thus the antiinflammatory activity of $G$. pinnata and B. pinnatum might 
be a major contributing factor for observed memoryenhancing activity [34, 35]. Oxygen-free radicals can generate neurotoxin and may act as a causative factor for the AD. The memory-boosting potency of both plants may be accredited to their free radical neutralizing capacity due to which liable neurons get affected by a lower amount of toxic free radical resulting in decreased neuronal toxicity and enhanced brain activity, thus boosting the cognitive power [23]. Also, the phenolic compounds can trigger the specific intracellular signaling pathway to improve memory process [36]. Consequently, higher phenolic content and antioxidant activity of the G. pinnata may have contributed to its higher memoryenhancing effect as compared to B. pinnatum in this study. In a previous study on the Swiss albino mice model, an aqueous extract of $B$. pinnatum (AEBP) at $200 \mathrm{mg} / \mathrm{kg}$ body weight had significantly controlled the sleeping time and other overall behaviors, induced by phenobarbitone along with delaying effect on the onset of picrotoxin and strychnine induced convulsion. B. pinnatum extract might exert depressive effects on the central nervous system as a result of its GABAergic and less commonly glycinergic transmission [37]. Memory-enhancing effect of $B$. pinnatum was also supported by a previous study, in which AEBP leaves had shown improvement of shortterm memory loss by suppressing $\mathrm{CCL}_{4}$ induced acetylcholinesterase activity. The leaf extract was very much prominent to reduce $\mathrm{CCL}_{4}$ induced nitric oxide $(\mathrm{NO})$ and malondialdehyde (MDA) overproduction in the brain to protect from oxidative stress. Increased MDA level is an indication of oxidative stress to result in oxidative damage of the brain. Oversynthesis of NO diminishes the function of antioxidant enzymes, hence leading to neurodegenerative diseases such as $\mathrm{AD}$ and depression [38]. Acetylcholine (ACh) is the major neurotransmitter of the cholinergic system associated with cognitive functions such as episodic and spatial memory, learning behavior, working memory, learning, and cerebral blood flow regulation [39]. Acetylcholine ( $\mathrm{ACh}$ ) concentration is controlled by enzyme acetylcholinesterase (AChE) which is capable of hydrolyzing this neurotransmitter. An increase in the concentration of AChE in the brain results in the degradation of Ach, eventually reducing the ACh receptors and then inducing undesirable effect on cholinergic neurotransmission, and also results in impairment of cognitive function as well as other neurological disorders [40]. Administration of AEBP leaves in the dose of 25 and $50 \mathrm{mg} / \mathrm{kg}$ body weight had resulted in prominent inhibition in AChE activity, in comparison to the negative control group and also it had resulted in a significant decrease in adenosine deaminase (ADA) concentration in the brain of albino mice. It was proven that increasing concentration of $\mathrm{ACh}$ in the synaptic cleft facilitates the cognitive functions, such as learning and memory, and modulation of cerebral blood flow. Increasing concentration of ADA is associated with the declination of neuron protective endogenous molecule adenosine $[38,39]$. The barks of $G$. pinnata contain different types of diarylheptanoids $[41,42]$, which are effective in neuron protection and cognition enhancement. These compounds can remarkably improve the amnesia, induced by scopolamine, in passive avoidance tests. The diarylheptanoids can significantly increase phosphorylation of the cyclic AMP response element-binding protein (CREB) and expression of brain-derived neurotrophic factor (BDNF) in the hippocampus and cortex of the scopolaminetreated mice. They also notably protected hippocampal HT22 cells from glutamate insult-induced neurotoxicity. Overall, diarylheptanoids may mitigate memory deficiency by activating the BDNF-CREB pathway and inhibit neuronal cell death to prevent neurodegeneration $[43,44]$. Besides, leaves of B. pinnatum and bark of $G$. pinnata were reported to present potent anti-inflammatory nonsteroidal derivatives [10], phytosterols, triterpenoids, alkaloids, glycosides, polyphenol, $\beta$-amyrin structure, and so on $[34,35,45,46]$. Flavonoids are present abundantly in both plants and several studies show that natural flavonoids can produce an anxiolytic effect without inducing sedation and amnesia $[47,48]$. Similarly, terpenoids are known to cause sedative and anxiolytic effects [32]. The precise mechanism of action remains to be explained but our findings are important as they validate one of the folk uses of the G. pinnata bark and B. pinnatum leaves as a medicinal plant in Nepal.

\section{Conclusion}

$G$. pinnata and B. pinnatum both contain bioactive phytoconstituents like alkaloids tannins, phenols, and flavonoids with free radical scavenging and memory-boosting ability. So, it is possible to utilize these plants for the management of cognitive impairment, related to AD. Besides, the significant memory-enhancing activity of these plants may be associated with their phenolic content and antioxidant potency. Further study is needed at the preclinical and clinical level with the elucidation of the exact mechanism.

\section{Data Availability}

All the data used to support the result of this research are available from R. Bhandari upon request.

\section{Disclosure}

This research was performed as part of the partial fulfillment of an academic degree at Crimson College of Technology, Nepal.

\section{Conflicts of Interest}

The authors declare no conflicts of interest.

\section{Acknowledgments}

The authors thank the Crimson College of Technology, affiliated to Pokhara University, Nepal, for all the technical support. 


\section{References}

[1] R. L. Nussbaum and C. E. Ellis, "Alzheimer's disease and Parkinson's disease," New England Journal of Medicine, vol. 348, no. 14, pp. 1356-1364, 2003.

[2] H. Hosseinzadeh, H. R. Sadeghnia, F. A. Ghaeni, V. S. Motamedshariaty, and S. A. Mohajeri, "Effects of saffron (crocus sativus L.) and its active constituent, crocin, on recognition and spatial memory after chronic cerebral hypoperfusion in rats," Phytotherapy Research, vol. 26, no. 3, pp. 381-386, 2012.

[3] H. Amin, K. Dhiman, R. Sharma, M. Vyas, and P. Prajapati, "Shankhapushpi(Convolvulus pluricaulisChoisy): validation of the Ayurvedic therapeutic claims through contemporary studies," International Journal of Green Pharmacy, vol. 8, no. 4, pp. 193-200, 2014.

[4] N. Sethiya, A. Nahata, S. H. Mishra, and V. K. Dixit, "An update on Shankhpushpi, a cognition-boosting Ayurvedic medicine," Journal of Chinese Integrative Medicine, vol. 7, no. 11, pp. 1001-1022, 2009.

[5] N. K. Sethiya, A. Nahata, P. K. Singh, and S. H. Mishra, "Neuropharmacological evaluation on four traditional herbs used as nervine tonic and commonly available as Shankhpushpi in India," Journal of Ayurveda and Integrative Medicine, vol. 10, no. 1, pp. 25-31, 2019.

[6] A. Nahata, U. K. Patil, and V. K. Dixit, "Effect of Evolvulus alsinoides Linn. On learning behavior and memory enhancement activity in rodents," Phytotherapy Research, vol. 24, no. 4, pp. 486-493, 2010.

[7] K. Sharma, M. Bhatnagar, and S. K. Kulkarni, "Effect of Convolvulus pluricaulis Choisy and Asparagus racemosus Willd on learning and memory in young and old mice: a comparative evaluation," Indian Journal of Experimental Biology, vol. 48, no. 5, pp. 479-485, 2010.

[8] A. Nahata, U. K. Patil, and V. K. Dixit, "Effect ofConvulvulus pluricaulisChoisy. on learning behaviour and memory enhancement activity in rodents," Natural Product Research, vol. 22, no. 16, pp. 1472-1482, 2008.

[9] K. S. Rai, K. D. Murthy, K. S. Karanth, and M. S. Rao, "Clitoria ternatea (Linn) root extract treatment during growth spurt period enhances learning and memory in rats," Indian Journal of Physiology and Pharmacology, vol. 45, no. 3, pp. 305-313, 2001.

[10] M. Afzal, I. Kazmi, R. Khan et al., "Bryophyllum pinnatum : a review," Int J Res Biol, vol. 2, no. 4, pp. 143-149, 2012.

[11] S. Pal and A. K. N. Chaudhuri, "Studies on the anti-ulcer activity of a Bryophyllum pinnatum leaf extract in experimental animals," Journal of Ethnopharmacology, vol. 33, no. 12, pp. 97-102, 1991.

[12] A. B. Shukla, D. R. Mandavia, M. J. Barvaliya, S. N Baxi, and C. R Tripathi, "Evaluation of anti-urolithiatic effect of aqueous extract of Bryophyllum pinnatum (Lam.) leaves using ethylene glycol-induced renal calculi," Avicenna Journal of Phytomedicine, vol. 4, no. 3, pp. 151-159, 2014.

[13] S Zaman, "Vitro evaluation of antimicrobial, antioxidant and cytotoxic activities of Garuga pinnata leaves," Indo Am J Pharm Sci, vol. 3, no. 3, pp. 294-299, 2016.

[14] W. C. Evans, Trease and Evans' Pharmacognosy International Edition E-Book, Elsevier Health Sciences, Amsterdam, The Netherlands, 2009.

[15] O. O. Odebiyi and E. A. Sofowora, "Phytochemical screening of Nigerian medicinal plants II," Lloydia, vol. 41, pp. 234-246, 1978.

[16] S. Tiwari, S. Nepal, S. Sigdel et al., "Phytochemical screening, antibacterial-guided fractionation, and thin-layer chromatographic pattern of the extract obtained from Diploknema butyracea," Pharmacognosy Research, vol. 12, no. 4, pp. 437-443, 2020.

[17] J. Pandey, T. Bastola, J. Tripathi et al., "Estimation of total quercetin and rutin content in malus domestica of Nepalese origin by HPLC method and determination of their antioxidative activity," Journal of Food Quality, vol. 2020, Article ID 8853426, 13 pages, 2020.

[18] D. Shrestha, J. Pandey, C. Gyawali et al., "Study of in vitro anti-oxidant and anti-diabetic activity by mussaenda macrophylla root extracts," International Journal of Current Pharmaceutical Research, vol. 12, no. 4, pp. 70-74, 2020.

[19] S. K. Pahari, S. P. Singh, M. P. Banmali, F. J. L. Thaler, and M. S. S. Rathour, Ethical Guidelines Forthe Care and Use of Animals in Health Research in Nepal, pp. 5-44, Nepal Health Research Council, Kathmandu, Nepal, 2005.

[20] R. Pantha, J. Pandey, N. Joshi et al., "Anti-urolithiatic property of Crataeva nurvala root and bark from Nepal on ethylene glycol induced urolithiatic mice," vol. 12, pp. 658$662,2020$.

[21] D. R. Marasini, J. Pandey, L. P. Sharma et al., "A original article analgesic activity of bark and leaves of Ficus religiosa L. from Nepal," International Journal of Pharmacy and Pharmaceutical Sciences, vol. 12, no. 7, pp. 32-35, 2020.

[22] OECD, Test No. 425: Acute Oral Toxicity: Up-And-Down Procedure, pp. 1-27, OECD, Paris, France, 2008.

[23] D. Dhingra, M. Parle, and S. K. Kulkarni, "Memory enhancing activity of Glycyrrhiza glabra in mice," Journal of Ethnopharmacology, vol. 91, no. 2-3, pp. 361-365, 2004.

[24] N. Savithramma, M. L. Rao, and D. Suhrulatha, "Screening of medicinal plants for secondary metabolites," Middle-East Journal of Scientific Research, vol. 8, no. 3, pp. 579-584, 2011.

[25] A. Shirwaikar, K. Rajendran, and R. Barik, "Effect ofGaruga pinnata. Roxb aqueous bark extract on tissue antioxidant activity in streptozotocin-nicotinamide-induced type II diabetic rats," Pharmaceutical Biology, vol. 45, no. 3, pp. 205-209, 2007.

[26] L. Akacha, J. Dikko, M. Khan, J. Anyam, and J. Igoli, "Phytochemical screening and antimicrobial activity of bryophyllum pinnatum extracts," British Biotechnology Journal, vol. 16, no. 2, pp. 1-8, 2016.

[27] N. Hazarika, P. Singh, and D. S. Hussain, "Phenolics content and antioxidant activity of crude extract of oldenlandia corymbosa and bryophyllum pinnatum," Research Journal of Pharmaceutical, Biological and Chemical Sciences, vol. 3, no. 2, pp. 297-303, 2012.

[28] S. Nair, S. Dixit, and N. Ganesh, "Comparative study of invitro antioxidant potential of crude extracts of bryophyllum pinnatum [(Lam) oken] leaves in different solvents and the invitro hypoglycemic potential of its hydroalcoholic extract," Journal of Chemical and Pharmaceutical Research, vol. 9, no. 2, pp. 237-243, 2017.

[29] H. Amiri, "Volatile constituents and antioxidant activity of flowers, stems and leaves of Nasturtium officinale R. Br," Natural Product Research, vol. 26, no. 2, pp. 109-115, 2012.

[30] S. O. Onoja, G. Q. Ihejirika, O. N. Nwankudu, Y. N. Omeh, and M. I. Ezeja, "Antidiarrheal and antioxidant activities of methanol extract of bryophyllum pinnatum leaf harvested from south-eastern Nigeria in mice," Journal of Pharmaceutics, vol. 2018, pp. 1-6, 2018.

[31] S. Sindhu and S. Manorama, "Exploration of antioxidant properties in various extracts of bryophyllum pinnatum (lank.)," Pharmaceutical Research, vol. 3, no. 4, pp. 1-8, 2013. 
[32] A. Nahata, U. K. Patil, and V. K. Dixit, "Anxiolytic activity ofEvolvulus alsinoidesandConvulvulus pluricaulisin rodents," Pharmaceutical Biology, vol. 47, no. 5, pp. 444-451, 2009.

[33] B. Chauhan and A. K. Chaudhary, "Memory enhancing activity of methanolic extract of Pterocarpus marsupium Roxb," Phytopharmacology, vol. 2, no. 1, pp. 72-80, 2012.

[34] M. K. Thupurani, R. P. Nisanth, C. M. A. Singara, and G Mittapelli, "In Vitro and in vivo determination of antiinflammatory activities of Garuga pinnata Roxb," International Journal of Pharmaceutical Sciences Review and Research, vol. 22, no. 2, pp. 310-314, 2013.

[35] J. A. O. Ojewole, "Antinociceptive, anti-inflammatory and antidiabetic effects of Bryophyllum pinnatum (Crassulaceae) leaf aqueous extract," Journal of Ethnopharmacology, vol. 99, no. 1, pp. 13-19, 2005.

[36] R. Dasari, D. Sathyavati, A. K. Belide, P. J. Reddy, and K. Abbulu, "Evaluation of antioxidant activity of two important memory enhancing medicinal plants Celtis timorensis and Vanda spathulata," Asian Journal of Pharmaceutical and Clinical Research, no. 2, pp. 153-155, 2013.

[37] H. Salahdeen and O. Yemitan, "Neuropharmacological effects of aqueous leaf extract of Bryophyllum pinnatum in mice," African Journal of Biomedical Research, vol. 9, no. 2, pp. 101-107, 2009.

[38] S. O. Anadozie, J. A. Akinyemi, O. B. Adewale, and C. C. Isitua, "Prevention of short-term memory impairment by Bryophyllum pinnatum (Lam.) Oken and its effect on acetylcholinesterase changes in CCl4-induced neurotoxicity in rats," Journal of Basic and Clinical Physiology and Pharmacology, pp. 1-10, 2019.

[39] I. Wessler and C. J. Kirkpatrick, "Acetylcholine beyond neurons: the non-neuronal cholinergic system in humans," British Journal of Pharmacology, vol. 154, no. 8, pp. 1558-1571, 2008.

[40] D. M. Lovinger, "Neurotransmitter roles in synaptic modulation, plasticity and learning in the dorsal striatum," Neuropharmacology, vol. 58, no. 7, pp. 951-961, 2010.

[41] K. Ara, A. H. M. M. Rahman, C. M. Hasan et al., "Macrocyclic diarylheptanoids from Garuga pinnata," Phytochemistry, vol. 67, no. 24, pp. 2659-2662, 2006.

[42] G. Venkatraman, A. K. Mishra, P. S. Thombare, and B. K. Sabata, "Diarylheptanoids from Garuga pinnata," Phytochemistry, vol. 33, no. 5, pp. 1221-1225, 1993.

[43] K. Y. Lee, E. J. Jeong, J. Huh et al., "Cognition-enhancing and neuroprotective activities of the standardized extract of Betula platyphylla bark and its major diarylheptanoids," Phytomedicine, vol. 19, no. 14, pp. 1315-1320, 2012.

[44] X. Huang, G. Tang, Y. Liao et al., "7-(4-Hydroxyphenyl)-1phenyl-4E-hepten-3-one, a diarylheptanoid from alpinia officinarum, protects neurons against amyloid- $\beta$ induced toxicity," Biological \& Pharmaceutical Bulletin, vol. 39, no. 12, pp. 1961-1967, 2016.

[45] A. Kamboj and A. K. Saluja, "Bryophyllum pinnatum (Lam.) Kurz.: phytochemical and pharmacological profile: a review," Pharmacognosy Reviews, vol. 3, no. 6, pp. 364-374, 2009.

[46] G. Venkatraman, P. S. Thombare, and B. K. Sabata, "Euphane triterpenoid from Garuga pinnata," Phytochemistry, vol. 32, no. 1, pp. 161-163, 1992.

[47] L. Guaraldo, D. A. Chagas, A. C. Konno, G. P. Korn, T. Pfiffer, and A. G. Nasello, "Hydroalcoholic extract and fractions of Davilla rugosa Poiret: effects on spontaneous motor activity and elevated plus-maze behavior," Journal of Ethnopharmacology, vol. 72, no. 1-2, pp. 61-67, 2000.
[48] F. F. Rocha, A. J. Lapa, and T. C. M. De Lima, "Evaluation of the anxiolytic-like effects of Cecropia glazioui Sneth in mice," Pharmacology Biochemistry and Behavior, vol. 71, no. 1-2, pp. 183-190, 2002. 